\title{
INTEGRATING DESIGN MANAGEMENT CONCEPT IN ENTREPRENEURIAL PRACTICES: EVIDENCE FROM THE CROSS-BORDER PROJECT
}

\author{
Laima Gerlitz \\ Wismar Business School Hochschule Wismar, University of Applied Sciences: Technology, \\ Business and Design Department of Business Administration, Tallinn University of Technology, \\ Corresponding address: Philipp-Müller-Str. 14, 23966 Wismar, Germany \\ E-mail: laima.gerlitz@hs-wismar.de
}

\begin{abstract}
Innovation is the key-driving factor for the economic grow and social wealth. Innovative products and services emerge more often as a result of cross-sectorial combination of technologies, design and business models. The European Union approved in summer 2011 within the South Baltic Programme the INTERREG IVA project 'Design EntrepreneurSHIP'. The project work follows the evolutionary approach that is supported by semi-structured interviews, qualitative and quantitative surveys and expert assessments. The paper presents accumulated results by highlighting expectations and needs of entrepreneurs concerning a SME-suitable design management concept and desired design management skills in SMEs, forging innovation and sustainable entrepreneurship growth.
\end{abstract}

Keywords: design management, innovation, entrepreneurship, small and medium-sized enterprises, competitiveness, technology-driven SMEs.

JEL Classification: O14, L26.

\section{Introduction}

For many, design is perceived in different ways, however, it is not negligible that design is a powerful tool (Kotler, Rath 1984) and most of us have been concerned with design in one or another way. Indeed, traditionally design has been affiliated with products and their uses, their shapes, colours, etc. or just been treated as a matter of mere styling. Today, however, design has been 'repositioned' and new possibilities were opened up for design to play: within manufacturing, business development, industrial and social innovation and, recently, digital economy domains (Inglewood, Youngs 2014). Design is used not just for manufacturing anymore, but also for life, becoming a driving force on the entire manufacturing process and the entire lifecycle (Elsy 2015). Indeed, as the scholarly discourses showcase, design has become an important tool related to the business development, innovation and entrepreneurship (Borja de Mozota 1998, 2003a, 2003b, 2006; Raulik et al. 2008; Cooper, Press 1995; Dumas, Mintzberg 1989; Walsh et al. 1992; Turner 2013). Myriads of research entries are discovered in the profound databases and journals on design and design management, its application in social or natural sciences, theoretically and practically. Its scope of application is notably multi-faceted. Design as an approach and tool opens up new perspectives in all challenged societal and economic arrays, through, e.g. inclusive design (integrating both customers / end-users and information needs) (Coleman et al. 2007; Bound, Coleman 2005), design for all, social design, ecodesign (Ljunberg 2007) or design for social responsibility (Persson et al. 2015; Bochinska 2011), collaborative design (Sebastian 2004), green design (Adhikary 2008) and sustainable design (Heylighen 2008; Novak 2014; Nielsen et al. 2009; Fargnoli et al. 2014; Laszlo, Cooperrider 2007).

Paradoxically, design integration within practice-oriented small business interactions, particular within the SMEs context has been largely marginalised (Moultrie et al. 2007: 335) or failed successful utilisation when compared to other type organisations or other business settings (Bruce et al. 1999; Dickson et al. 1995; Walsh, Roy 1985). There is to less attention have been paid towards revealing design impact, design practices and implications within smaller enterprises (Gemser, Lenders 2001; Hertenstein et al. 2005; Moultrie et al. 2007; Fernández-Mesa et al. 2013; Erichsen 2014; Kortesoja 2013; Maroni et al. 2015).

Yet, as claimed in numerous European policy papers, SME sector is the backbone of the EU economy, with SMEs being micro with (up to 10), small with (up to 50) and medium-sized with (up to 250) employees (EU 2015). Communication of 
the European Commission COM (2012) "Entrepreneurship 2020 Action Plan - Reigniting the Entrepreneurial Spirit in Europe" stresses that future growth and competitiveness needs to be smart, sustainable and inclusive addressing our principal societal challenges (2012: 3 ).

Having such research landscape, there is an increasing impetus to provide smaller enterprises with potential guides on how to harvest design for operational efficiency and effectiveness, strategic orientation and acknowledgement by customers and end-users. Indeed, the EU-funded (ERDF) Interreg IVA project named 'Design EntrepreneurSHIP' declared the will to reduce this challenge and provide European SMEs with specific SMEsuited concept how to integrate creativity and design into entrepreneurial practices and to benefit for innovation and growth. The present paper builds therefore on key tenets relating to SMEs strategic orientation, innovation, competitiveness and growth and presents the design-driven approach, practice-oriented approach for SMEs based on the empirical inquiry - design management model. The author argues that design integration within business interactions may lead towards entrepreneurial success expressed through variables such as increased innovation capacity, better competitiveness or growth potential.

\section{Theoretical framework}

Taking into account the common conceptual thread of the affiliated approaches, design and management may result in design management perspective, a concept, which is still being highly debatable, depending on the scholarly or research array the angle therefore is placed on design. There are myriad of definitions proposed by scholars and practitioners (Best 2015). Already by 1998, the Design Management Journal counted more than 18 different views on the definition of design management (p. 14). Over the last 50 years, new areas of application enter the scientific and practiceoriented discourses, and new definitions were formulated. However, taking into account the research objectives, the best suitable definition of design management to be applied in the present research environment is that one that links the peculiarities of design process, design being an act and outcome with positive impact on entrepreneurial competitiveness, innovation and smart growth, i.e. an interdisciplinary, process-based approach (Hack et al. 2012; Prause et al. 2012; Er 1997; Martin 2009; Brown 2008; Brown, Wyatt 2010; Best 2011, 2015; Kaivo-oja 2012; Whyte et al. 2015, etc.).
Today it is widely acknowledged that design management gains an increasing importance in providing companies with transformation value, i.e. where design is particularly employed not to manage projects but rather utilised as a core strategic resource and organisational capability, activity, process or phenomenon presenting the creative industry (Borja de Mozota, Kim 2009: 69). Design, the same applies for innovation, can be used as a noun or verb. The focus is on how the design process can be organised and managed towards product and service innovations on corporate and community (users) levels, thus creating a value (Whyte et al. 2015: 2) and enabling organisations to differentiate and position on the market (Porter 1985: 35, 1991: 103, 1996: 70). Although design is not only about invention, i.e. creating something totally new, it is a way of making (in)tangible impact through the implementation of ideas, i.e. design of products, services and experiences that touch, change and improve people's daily lives. Design, the same applies for innovation, introduces a new meaning and value for its consumers, i.e. a new or significantly improved good or service, process or new marketing method, new organisational methods in business practice, workplace organisation or external relations (OECD/ European Communities 2005: 46; Trott 2012: 12-15).

Acknowledging design's value for organisations, its power to differentiate, position on the market and improve functionality of internal processes and external appearance of organisations (products, services), design can be viewed as a strategic resource. Following Resource-Based View (RBV), resources are all tangible and intangible assets, capabilities, organisational processes, attributes, information, knowledge etc., i.e. all potential, which, in turn, when controlled by the enterprise allows it to recognise and implement strategies bringing organisational efficiency and efficacy (Barney 1991: 101; Crook et al. 2008: $1150-1152$ ). Design is a resource, because it is a process (Whyte et al. 2015: 2; Er 1997: 293; Hack et al. 2012: 140-141). It is a resource, since design may bring value through being hardly duplicable, imperfectly imitable and non-substitutable (Barney 1991: 105-106; Boxall 1996: 65), it may influence products through giving them sense. Being design as a source of making sense of things, design implies messages to users, within the styling (e.g. form), functionality of a product, service or process (technology, cost), emotional and symbolic value, i.e. meaning. Meaning proposes to users a system of values by using a specific language, e.g. signs, symbols and icons that deliver the message 
(Verganti 2008: 440). Thus, it is hardly to duplicate and imitate design, when a specific sense is given through design to a certain product, service or a process. Design is also knowledge, as it is used to generate new meanings or forms (Jonas 2011: 1). Design may be perceived as capability too, capacity to deploy design resources (Amit, Schoemaker 1993: 35-37), dynamic capability in today's world (Teece et al. 1997: 516; Jevnaker 1998: 21). As a result, design can be used as an organisational asset as well as information for competitive advantage. Through combination of new information flows, organisation gets ability to exploit new linkages between its activities internally and externally (Porter, Millar 1985: 152). Design becomes a valuable resource, as it enables to differentiate, integrate, transform and be a good business practice (Borja de Mozota 2006: 45). Further, understanding design as a resource may create and offer a value proposition, reach markets, maintain relationships with customer segments and earn revenues (Osterwalder et al. 2014: 152).

\section{Methodology}

The present research applied a hybrid research approach (Fereday, Muir-Cochrane 2006: 80) combining inductive and deductive perspectives, analysing and identifying to capture the key phenomenon - design integration and its value for SMEs by design management model. The paper has pursued a manifold research path, whereby diverse research methods have been combined with the respective research approach and research tool. Five techniques were employed in exploring the objectives of the present paper:

- Research type: analytical, qualitative, practice-based and exploratory.

- Research approach: qualitative.

- Research method: qualitative - case studies, semi-structured interviews, expert assessments, trainings presentations, observations, field notes and memos.

- Research tool: design management concept.

- Research scope: 2011-2015.

The paper applies a qualitative research approach and discusses the value of design management for SMEs, which participated within the project 'Design EntrepreneurSHIP' in the time frame 2011-2015. Qualitative approach has been frequently utilised for the research purposes within academic design management research and related discourses, mainly driven by case study method (e.g. Borja de Mozota 2006, 2013; Millward et al.
2006; Acklin 2011, 2013, etc.) and a series of studies conducted by the Design Management Institute (DMI), USA. Similarly, in case of studies on innovation related practices, scholars tend using qualitative case analysis also in developing a conceptual model. As a result, conceptual model can be derived from SMEs practices (cases) overt a longitudinal period (Shaw 1999: 62ff).

SMEs, who take part in the project, are referred here to as individual cases comprising the macro case study (project). In total, eight SMEs were subject to the scrutiny and evaluation. Research on design management within innovation and growth, i.e. product, service or organisational development processes, i.e. creative processes, is more likely to deploy case studies accompanied by semi-structured interviews (e.g. Roy, Reidel 1997; Bruce et al. 1999). Already Svengren (1993: 444) recognised the importance of case study in dealing with design management as opposed to action research. As a result, a cross-case or multiple case (also collective) analysis (Eisenhardt 1989; Miles Huberman 1994: 101; Stake 1995: 4-6; Yin 2009, 2012), thematic/content analysis, template (concept) based approach to analysis to explore the data gathered at a predefined scheme identified prior the analysis as well as generated inductively from the data (Crabtree, Miller 1992: 93-109, etc.) were employed. The analysis results of design application and exploitation are presented in a narrative way. Indeed, integration, analysis and evaluation of case studies, i.e. decomposition of company's performance (Borja de Mozota 2013: 305) and presentation of result enables to showcase the partnership between design and management and to reveal the complexity of the phenomenon. Particularly, the project is viewed as a collective case, whereas SMEs as individual cases. These build basis for cross-sectorial and cross-case analysis and justification of the design management phenomenon and its impact within different operational and environment setting. Here, the results and validation are grounded on the insights from the individual SMEs and their specific cases solved (SMEs cases). Each SME has a different case portfolio available for the project, depending on enterprise's operational or environmental scope, problem or challenge complexity. These SMEs cases were solved during the project life and bear reallife scenarios that imply a problem, a challenge or a particular search for a business opportunity. In brief, the project was designed in a manner that during interdisciplinary, international and crosssectorial training sessions with a number of three per project year, real-life problems or challenges 
provided by SMEs, i.e. specific cases from Germany, Poland and Sweden were dealt with by intercultural, interdisciplinary and international project teams consisting of students, graduates, start-ups and experts from these three countries and renown experts worldwide. Thus, a number of SMEs participated during a project year with eight SMEs in total and ten training sessions conducted.

Table 1. Empirical body matrix (Source: compiled by the author)

\begin{tabular}{l|l|l|l}
\hline $\begin{array}{l}\text { Collective } \\
\text { case }\end{array}$ & No. & Training case & SME scope \\
\hline \multirow{4}{*}{$\begin{array}{l}\text { Training } \\
\text { cycle I }\end{array}$} & \multirow{2}{*}{\begin{tabular}{l} 
Wismar 2012 \\
\cline { 3 - 3 }
\end{tabular}} & Gdynia 2012 & SME 1 \\
\cline { 3 - 4 } & & Stockholm 2012 & $\begin{array}{l}\text { Not direct } \\
\text { SME case }\end{array}$ \\
\hline \multirow{4}{*}{$\begin{array}{l}\text { Training } \\
\text { cycle II }\end{array}$} & 2 & Rostock 2013 & SME 3 \\
\cline { 3 - 4 } & & Galmö 2014 & $\begin{array}{l}\text { Not direct } \\
\text { SME case }\end{array}$ \\
\hline \multirow{3}{*}{$\begin{array}{l}\text { Training } \\
\text { cycle III }\end{array}$} & 3 & Wismar 2014 & $\begin{array}{l}\text { Not direct } \\
\text { SME case }\end{array}$ \\
\cline { 3 - 4 } & & $\begin{array}{l}\text { Kronovall/Malmö } \\
\text { 2014 }\end{array}$ & SME 6 \\
\hline $\begin{array}{l}\text { Grand } \\
\text { Showcase } \\
\text { Training } \\
\text { Session }\end{array}$ & G & Gdynia 2014 & SME 7 \\
\cline { 3 - 4 } & & & SME 8 \\
\hline
\end{tabular}

A consolidating grand training session with two additional SMEs round off the trainings and cases. In sum, three project years stand for three project milestones or three training cycles with three enterprise cases solved per year and two additional. The project treats eight SMEs in three training cycles, as the remaining three enterprises or organisations are not directly referred to as SMEs, and are therefore out of this research scope. Added to this are two additional SMEs from the Grand Showcase training session, with a total eight SMEs cases. The project gathered more than 120 design management practitioners, absorbers, developers and experts.

\section{Results from cross-case analysis}

Taking a look at all the SMEs under scrutiny as well as design management approaches applied within other trainings, which do involve enterprises, however that of larger operational scale or different nature (e.g. those of public interest), it is evident that design is likely to be the driving force on operational, strategic, and socio-environmental level of the enterprise (its external performance on the market and linkage with customers). It implies a common thread embedded in all enterprise interactions, from the manufactured goods, over service proposition and customer management related to produced goods or services towards self-supporting value networks. Indeed, design has been observed as a powerful source, resource, networking, organisational, coordination, integration and value sharing capability. It is indispensable knowledge and information, which can lead to product, service or process innovation, strengthened competitiveness and stronger performance internally and externally on the market as well as provide with better opportunities for business growth of SMEs.

In the following, the paper does not discuss the individual cases in detail due to limited scope. Thus, the cases were broken down in specific aggregated themes with regard to their contents, necessary to reveal the contribution of design to innovation on operation and strategic level in the economic and social context. As a result, the landscape of cases is presented only to what is necessary from the research objective point of view. The results gathered from the empirical inquiry are displayed in such a way that they reveal potential of innovations for SMEs (1), competitiveness (2) and growth path (3).

As the theoretical treatises of scholars suggest, innovation is key to both - competitiveness and growth. Indeed, the empirical evidence from all eight SMEs individual cases and SMEs cases dealt with support this contention. Enterprise, driven by design as an incremental process, is capable to generate and exploit innovation capacity for developing, producing and capitalising products, services or process within organisation itself. Design becomes a driver. Initially, innovation has been highly affiliated with the field of R\&D (OECD/EC, 2005) and could hardly be allocated to the primary activities of the supply chain of an organisation needed for operational practices (Porter 1985). Indeed, it was believed that innovation is not a crucial precondition for products or services to be delivered along the supply and value chains.

Yet, the SMEs cases reveal that innovation does not evolve just in the R\&D line of the supply chain, i.e. is pulled by technologies, but is rather result of smart combinations of resources, activities and capabilities residing in technological, business and design domain. In fact, design when combined to technology and managerial perspective may lead towards new meanings and value creation for its customers, i.e. new or significantly 
improved good or service, process, new marketing or organisational method in business practice or external relations. This is also true for innovations, which enable solving a problem, developing a new idea, manufacturing and marketing a new construct, would it be product, service or process itself. Innovation is a process turning opportunity into new idea and ensuring its practical application in reality (Tidd, Bessant 2013: 18-22) and bringing value through its availability and access to it for its users via the market and/or other channels or distributed peer-to-peer and/or by the market (Gault, 2012: 9). Design is a tangible outcome, i.e. end product of the process or intangible, e.g. service or process, solution, etc. (von Stamm 2004:11).

Innovations are driven by design and emerge as a result of smart design integration and are aggregation with technological and business readiness. Mainly, these innovations are referred to as 'the 4Ps of innovation space' (process, paradigm (organisational), product and position (context or market), as introduced by Tidd and Bessant (2013: 24-29) and OECD/ European Communities (2005: 47). It is here to mention that also innovation is regarded as innovation when realised and exploited on the market, thus distinguishing it from invention, which implies just discovery of new product, service or process, the researcher acknowledges the proposed solutions for SMEs as innovative design-driven solutions or potential innovations (Kel- ler 2004: 243; Fagerberg et al. 2006: 5ff). It is notably believed that such innovative smart solutions will be realised as real-life innovations in the next future, since the time beyond the project is still too short to successfully commercialise the developed solutions on the market by the pilot SMEs.

As the project results' canvas in Figure 1 demonstrates, innovation can be notably traced within product, service or position domain. Indeed, integration of design within business and technological organisational dimensions can streamline operational efficiency, enhance strategic enterprise orientation or improve perception within external setting - socio-cultural environment or on the market. Design is treated as a domain of innovation, thus enabling innovation generation driven by design or design-driven innovation.

The empirical results yield that design is a source of innovation within enterprise. It also implies important development process within enterprise, improves production or service provision development and processes. Design improves products, services and processes in SMEs in their aesthetics, form and functionality. It enables achievement of desired or demanded by costumers' quality, efficiency, usability, durability, reliability, etc. Design also supports development of new technologies, new technological combinations and aggregations, methods and tools.

Table 2. Design-driven innovation in SMEs (Source: compiled by the author)

\begin{tabular}{c|l|l|l}
\hline SME & \multicolumn{1}{|c|}{ SME case } & \multicolumn{1}{|c|}{ Innovativeness form } & \multicolumn{1}{c}{ Innovation space } \\
\hline SME 1 & Fuel cell system & $\begin{array}{l}\text { Marketing and corporate identity strategy, brand- } \\
\text { ing, business strategy }\end{array}$ & $\begin{array}{l}\text { Product, service, } \\
\text { process \& position }\end{array}$ \\
\hline SME 2 & Heating \& ventilation & $\begin{array}{l}\text { New forms of product, service, increased techno- } \\
\text { logical product efficiency, improved functionality, } \\
\text { marketing method }\end{array}$ & $\begin{array}{l}\text { Product, service, } \\
\text { position }\end{array}$ \\
\hline SME 3 & Building constructions & $\begin{array}{l}\text { Solutions for customer experience, product deliv- } \\
\text { ery channels, products combined with socio- } \\
\text { economic environment (customer \& end-users } \\
\text { orientation) }\end{array}$ & $\begin{array}{l}\text { Product, service, } \\
\text { process \& position }\end{array}$ \\
\hline SME 4 & $\begin{array}{l}\text { Bathroom \& leisure furni- } \\
\text { ture made of Corian }\end{array}$ & $\begin{array}{l}\text { Product modular systems, product applications, } \\
\text { customers groups, market entry proposals }\end{array}$ & $\begin{array}{l}\text { Product, service, } \\
\text { position }\end{array}$ \\
\hline SME 5 & $\begin{array}{l}\text { Miniature electronic } \\
\text { systems }\end{array}$ & $\begin{array}{l}\text { Product applications, business strategy } \\
\text { Customer groups }\end{array}$ & $\begin{array}{l}\text { Product, service \& } \\
\text { position }\end{array}$ \\
\hline SME 6 & Apple products & $\begin{array}{l}\text { End-users engagement and loyalty building, ex- } \\
\text { tended product portfolio }\end{array}$ & $\begin{array}{l}\text { Product, service, } \\
\text { position }\end{array}$ \\
\hline SME 7 & Robots \& robotic systems & $\begin{array}{l}\text { Marketing \& communication strategy, corporate } \\
\text { identity, branding }\end{array}$ & $\begin{array}{l}\text { Product, service, } \\
\text { process \& position }\end{array}$ \\
\hline SME 8 & $\begin{array}{l}\text { Interior decoration \& } \\
\text { polymer processing }\end{array}$ & $\begin{array}{l}\text { Communication strategy } \\
\text { Product applications }\end{array}$ & $\begin{array}{l}\text { Product, service, } \\
\text { process \& position }\end{array}$ \\
\hline
\end{tabular}




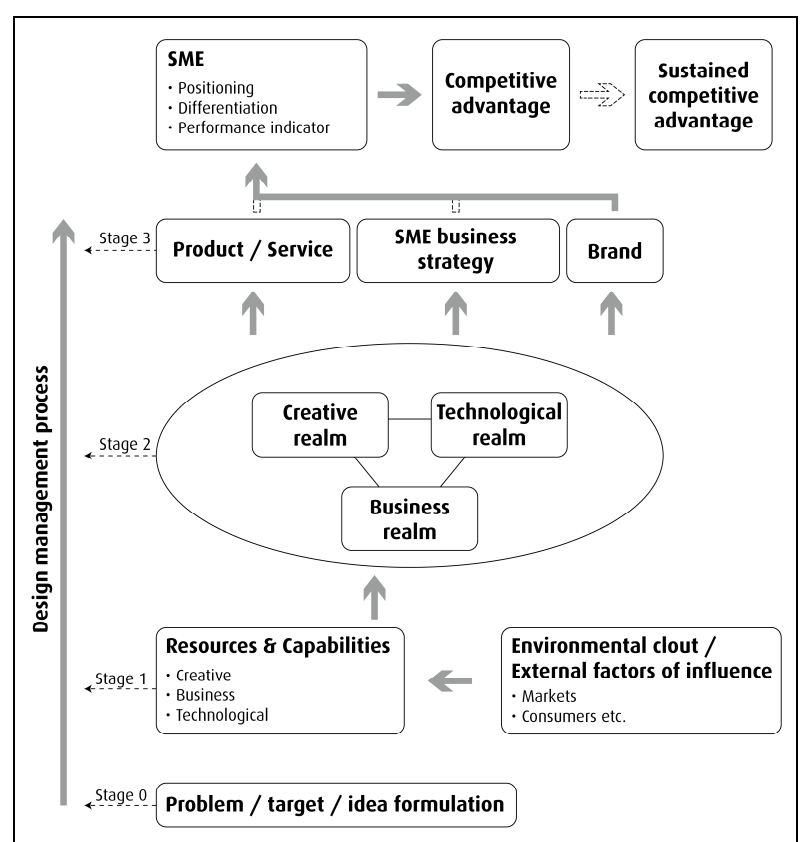

Fig. 1. Design management concept for SMEs (Source: compiled by the author)

From the empirical inquiry it becomes evident that design integration may lead to different constellations or aggregations of innovation, diverse innovation space and different level of innovativeness. As the empirical data suggest, design integration supports in all the eight pilot SMEs generation of innovation potential by providing innovative solutions, even if they are not commercialised on the market yet. However, these solutions are reliable and feasible propositions for SMEs, which, it is argued and believed, will be exploited on the market in the next future, thus enabling to trace design value. Mainly, design integration leads towards improved product or service portfolio, better understanding of enterprise itself as well as external perception on the market. Being a resource for enterprise positioning and enabling enterprise to sustain it with improved product or service quality, durable and reliable products, which better meet the needs of customers and end-users, enterprises are able to improve their competitive edge. Furthermore, improved product, service or internal process innovative solutions provide SMEs with clear opportunities for growth, e.g. through identification of new markets, new customers and endusers groups, new applications of products or services in different socio-economic or socio-cultural environment, etc.

In fact, it can be argued that innovation and design being innovation itself or design linked with innovation through creative process and creativity embeddedness (von Stamm 2004: 11) is key towards enterprise competitiveness and growth, as hypothesised in the research question. Particularly, design enables to 'design', i.e. develop innovative solutions matching the needs and requirements of both - entrepreneurs and the society - customers and end-users. In this, it is valuable internally within enterprise and externally on the market. The developed solutions suggest clear linkage of functional, aesthetical, meaning and visual match expressed through a form (product) or solution (service or process). Indeed, the implemented solutions notably reinforce the functional dimension. Moreover, design integration allows product development from the idea towards the maturity phase. Specifically, different number of developed solutions provides SMEs with key strategic strengths - capability to diversify and differentiate from the other. Diversification is possible through application of solutions to a range of options, modifications, new combinations, etc. thus enabling quantification of design-driven innovative solutions. This, again, may lead to business growth, entry of new markets or engagement of new customers and end-users groups. Thus, design being key innovation source and designer as key enabler to innovate allows developing smart and sustainable solutions.

\section{Discussion}

The analysis of empirical data suggests that design alone does not bear such innovation potential for products, services, organisational processes or improvement of enterprise's positioning. By contrast, as the SMEs' cases display, SMEs, who wanted to have solely design solutions to be developed, e.g. in case of SME 4, who wished to have new designs for bathroom or leisure furniture applications or SME 8 aimed to have a new vessel / container design, were proposed with solutions, which tackle, challenge or target their external performance on the market, internal organisation processes or are directly linked to technological and functional dimension of their products, services produced and delivered. This, indeed, leads towards proposition that effective design integration and design management in an enterprise needs to link up creative, managerial and technological capacities and capabilities. Concentration of the focus solely on design and its isolation from the fields of business and technology may negatively affect business practices.

The designer, economist or manager and engineer should cooperate to achieve complex structure and ensure combination of form, shape with functionality and customer needs. Respectively, business activities of a particular enterprise should 
not be restricted to management, design or technology. In fact, just by combining these three arrays the enterprise can transfer to successful business entity. Similarly, all three fields need to be involved within design management process. As a result, the research results suggest that design being a heart of innovation or innovation itself is able to provide with the value combining operational and strategic dimension of enterprise (Fig. 1).

Value is expression of competitive strength. It manifests through first, innovative product, service or processes solutions, second, competitiveness, business modelling and strategy or the ultimate achievement of competitiveness, the brand. The interplay of all three arrays reflects the cooperation patterns within a given SME, since there exists a mutual interdependence between these particular fields. Besides, an important implication of close dovetailing of the creative, business and technological realm appears to be the communication within SMEs. Due to the common communication there might result an effective cooperation of all three terrains.

\section{Concluding observations and implications}

From strategic intent, it might be argued then that design can be strategically deployed and exploited for innovations. Strategic acting of design within the business frame can be delineated as a critical dynamic collaboration across operational and management practices of organisations or companies successfully utilising design capabilities. For this, design integration for innovations resulting in value proposition on corporate level have positive implications for operational and strategic indications and provides with new opportunities. On the operational level, design integration might lead towards increased operational and economic efficiency, environmental efficiency (e.g. lower carbon footprint, less energy consumption) and social efficiency (e.g. individual customisation, user engagement and acceptance, customers loyalty). From the strategic point of view, design positively affects enterprise, since it enables diversification of activities, products and services. Design streamlines differentiation and positioning, supports strategic flexibility, resource efficiency, customers and end-user satisfaction. It creates value, provides with competitive advantage and enables better predictability in terms of competition, innovation potential, market penetration and similar. Indeed, design is valuable resource, an innovation within the enterprise operational and strategic interactions.
The observed design management practices and validation of design impact for innovation, competitiveness and growth is not free from limitations. The main limitation remains, however, sectorial concentration when dealing with SMEs, since the research focused on design practices within high technology driven or manufacturing SMEs. In the future research, the focus could be placed therefore on polarising perspectives of manufacturing and only servicing small and medium-sized enterprises. Further, future research should support design management model application by measuring design value and employ a higher number of SMEs cases, thus enabling quantified validation of the design management model. Further, comparative analyses could be done showcasing after the certain time lapse, how the provided innovative solutions for pilot eight SMEs turned into real innovations, commercialised on the market or exploited in another way. The analysis conducted and generalisations made imply, however, that further deepening of the proposed approach by incorporating further research methods and a broader sample may yield additional fruitful insights and knowledge as well as anchor the holistic view on design management within the topical discourses. Nevertheless, the managerial positive implications of such an approach for European SMEs already proved to be a success, as the empirical data yield. Providing a practice-oriented incremental design management model might also be regarded as supporting design-driven innovation application, innovation capacity building demanded in the European policy papers and SMEs discourses and enriching the topical literature.

\section{References}

Acklin, C. 2013. Design management absorption model - a framework to describe the absorption process of design knowledge by SMEs with little or no prior design experience, Creativity and Innovation management 22(2): 147-160. https://dx.doi.org/10.1111/caim.12022

Acklin, C. 2011. The absorption of design management capabilities in SMEs with little or no prior design experience, Nordes 4(2011): 1-10.

Adhikary, R. 2008. the promise of green design, Design Management Review 19(4): 22-29.

https://dx.doi.org/10.1111/j.1948-7169.2008.tb00137.x

Amit, R.; Schoemaker, P. J. H. 1993. Strategic assets and organisational rent, Strategic Management Journal (14) 1: 33-46. http://dx.doi.org/10.1002/smj.4250140105 
Barney, J. B. 1991. Firm resources and sustained competitive advantage, Journal of Management (17)1: 99-120. http://dx.doi.org/10.1177/014920639101700108

Best, K. 2011. What can design bring to strategy? Designing thinking as a tool for innovation and change. Inholland University of Applied Research in Rotterdam, 1-47.

Best, K. 2015. Design management: managing design strategy, process and implementation. Bloomsbury Publishing, $216 \mathrm{p}$.

Bochinska, B. 2011. Poland welcomes a world of socially responsible design, Design Management Review (22)1: 24-32.

https://dx.doi.org/10.1111/j.1948-7169.2011.00107.x

Borja de Mozota, B. 1998. Structuring strategic design management: Michael Porter's value chain, Design Management Journal, Spring 9(2): 26-31.

https://dx.doi.org/10.1111/j.1948-7169.1998.tb00201.x

Borja de Mozota, B. 2003a. Design and competitive edge: a model for design management excellence in European SMEs, Design Management Journal Academic Review 2: 88-103.

https://dx.doi.org/10.1111/j.1948-7177.2002.tb00014.x

Borja de Mozota, B. 2003b. Design management. using design to build brand value and corporate innovation. New York: Allworth Press, 281 p.

Borja de Mozota, B. 2006. The four powers of design: a value model in design management, Design Management Review 17(2): 44-53.

https://dx.doi.org/10.1111/j.1948-7169.2006.tb00038.x

Borja de Mozota, B. 2013. Design strategic value revisited: a dynamic theory for design as organisational function, in Cooper, R.; Junginger, S.; Lockwood, T. (Eds.). The handbook of design management. Bloomsbury Academic, 295-310.

Borja de Mozota, B.; Kim, B. Y. 2009. Managing design as a core competence: lessons from Korea, Design Management Review 20(2): 67-76.

https://dx.doi.org/110.1111/j.1948-7169.2009.00009.x

Bound, J.; Coleman, R. 2005. Commercial advantage from inclusive design, Design Management Review 16(3): 56-63.

https://dx.doi.org/10.1111/j.1948-7169.2005.tb00204.x

Boxall, P. 1996. The strategic HRM debate and the resource-based view of the firm, Human Resource Management Journal (6)3: 59-75.

https://dx.doi.org/10.1111/j.1748-8583.1996.tb00412.x

Brown, T. 2008. Design thinking, Harvard Business Review June: 1-10.

Brown, T.; Wyatt, J. 2010. Design thinking for social innovation, Stanford Social Innovation Review 8(1): 31-35.

Bruce, M.; Cooper, R.; Vazquez, J. 1999. Effective design management for small businesses, Design Studies (29)3: 297-315.

https://dx.doi.org/10.1016/S0142-694X(98)00022-2
Coleman, R.; Clarkson, J.; Dong, H.; Cassim, J. 2007. Design for inclusivity: a practical guide to accessible, innovative and user-centred design (design for social responsibility). Padstow: Gower Publishing Ltd., 246 p.

Cooper, R.; Press, M. 1995. The design agenda: a guide to successful design management. Chichester: John Wiley \& Sons, $298 \mathrm{p}$.

Crabtree, B. F.; Miller, W. 1992. Doing qualitative research. Newbury Park, CA: Sage, 298 p.

Crook, T. R.; Ketchen Jr., D. J.; Combs, J. G.; Todd, S. Y. 2008. Strategic resources and performance: a meta-analysis, Strategic Management Journal 29: 1141-1154. https://dx.doi.org/10.1002/smj.703

Design Management Journal DMJ. 1998. 18 Views on the definition of design management, Design Management Journal (9)3: 14-19.

https://dx.doi.org/10.1111/j.1948-7169.1998.tb00211.x

Dickson, P.; Schneider, W.; Lawrence, P.; Hytry, R. 1995. Managing design in small high growth companies, Journal of Product Innovation Management 12(5): 406-415. https://dx.doi.org/10.1111/1540-5885.1250406

Dumas, A.; Mintzberg, H. 1989. Managing design, designing management, Design Management Journal (1) $1: 37-43$.

https://dx.doi.org/10.1111/j.1948-7169.1989.tb00519.x

Eisenhardt, K. M. 1989. Building theories from case study research, The Academy of Management Review 4(14): 532-550.

Elsy, D. 2015. Design for life, not just for manufacture [online], [cited 06 May 2015]. Available from Internet: http://www.designcouncil.org.uk/newsopinion/design-life-not-just-manufacture

Er, H. A. 1997. Development patterns of industrial design in the third world: a conceptual model for newly industrialised countries, Journal of Design History 10(3): 293-307. https://dx.doi.org/10.1093/jdh/10.3.293

Erichsen, P. G. 2014. Design integration - a theoretical and empirical study of design integration in small and medium sized Danish companies. Syddansk Universitetsforlag.

European Commission. 2012. Entrepreneurship 2020 action plan - reigniting the entrepreneurial spirit in Europe, communication from the commission to the European Parliament, the Council, the European Economic and Social Committee and the Committee of the Regions, COM (2012) 795 final. Brussels.

European Commission (EU). 2015. User guide to the SME definition, Luxembourg: Publications Office of the European Union, 2015

Fagerberg, J.; Mowery, D. C.; Nelson, R. R. 2006. The Oxford handbook of innovation. New York: Oxford University Press, $656 \mathrm{p}$. 
Fargnoli, M.; Deminicis, M.; Tronci, M. 2014. Design management for sustainability: an integrated approach for the development of sustainable products, Journal of Engineering and Technology Management 34: 29-45.

https://dx.doi.org/10.1016/j.jengtecman.2013.09.005

Fereday, J.; Muir-Cochrane, E. 2006. Demonstrating rigor using thematic analysis: a hybrid approach of inductive and deductive coding and theme development, International journal of qualitative methods 5(1): 80-92.

Fernández-Mesa, A.; Alegre-Vidal, J.; ChivaGómez, R.; Gutiérrez-Gracia, A. 2013. Design management capability and product innovation in SMEs, Management Decision 51(3): 547-565. https://dx.doi.org/10.1108/00251741311309652

Gault, F. 2012. User innovation and the market, Science and Public Policy 39(1): 118-128. https://dx.doi.org/10.1093/scipol/scs005

Gemser, G.; Leenders, M. A. 2001. How integrating industrial design in the product development process impacts on company performance, Journal of Product Innovation Management 18: 28-38.

https://dx.doi.org/10.1016/S0737-6782(00)00069-2

Hack, A.; Prause, G.; Maknyte (Gerlitz), L. 2012. Design management and branding for SMEs: experiences from the DesignSHIP, in T. Muravska; G. Prause (Eds.). European integration and Baltic sea region studies: University-Business Partnership through the Triple Helix approach, Berlin: Berliner Wissenschafts-Verlag, 129-148.

Hertenstein, J. H.; Blatt, M. B.; Veryzer, R. W. 2005. The impact of industrial design effectiveness on corporate financial performance, Journal of Product Innovation Management 22(1): 3-21.

https://dx.doi.org/10.1111/j.0737-6782.2005.00100.x

Heylighen, A. 2008. Sustainable and inclusive design: a matter od knowledge?, Local Environment 13(6): 531-540. https://dx.doi.org/10.1080/13549830802259938

Inglewood, R.; Youngs, G. 2014. Designing the digital economy - embedding growth through design, innovation and technology. California: Design Commission.

Jevnaker, B. H. 1998. Building up organizational capabilities in design, in M. Bruce; B. H. Jevnaker (Eds.). Management of design alliances. Sustaining competitive advantage. Chichester: John Wiley \& Sons, 13-38.

Jonas, W. 2011. A sense of vertigo. Design thinking as a general problem solver?. in $9^{\text {th }}$ European Academy of Design Conference (EAD), May 2011, Portugal, $1-11$.

Kaivo-oja, J. 2012. Service science, service architecture, service design and dynamic service business development, in T. Kuosa; L. Westerlund (Eds.). Service design - on the evolution of design expertise: Research Report 16. Lahti, 69-82.
Keller, R. T. 2004. A resource-based study of new product development: predicting five-year later commercial success and speed to market, International Journal of Innovation Management 8(3): 243-260. https://dx.doi.org/10.1142/S1363919604001040

Kortesoja, J. 2013. Design management in a startup: a multiple case study on managing the visual product identity in 13 startup companies. Aalto University.

Kotler, P.; Rath, G. A. 1984. Design: a powerful but neglected strategic tool, Journal of Business Strategy 5(2): 16-21.

http://dx.doi.org/10.1108/eb039054

Laszlo, C.; Cooperrider, D. L. 2007. Design for sustainable value: a whole system approach, in M. Avital; R. J. Boland; D. L. Cooperrider (Eds.). Designing information and organizations with a positive lens, Vol. 2: Advances in appreciative inquiry. Bingley: Emerald Group, 15-29. http://dx.doi.org/10.1016/S1475-9152(07)00202-5

Ljunberg, L. Y. 2007. Materials selection and design for development of sustainable products, Materials and Design 28: 466-479.

https://dx.doi.org/10.1016/j.matdes.2005.09.006

Maroni, I.; Arruda, A.; Araujo, K. 2015. The design and technological innovation: how to understand the growth of start-ups companies in competitive business environment, Procedia Manufacturing 2: 2199-2204. https://dx.doi.org/10.1016/j.promfg.2015.07.361

Martin, R. 2009. The design of business: why design thinking is the next competitive advantage. Boston: Harvard Business Press, 208 p.

Miles, M. B.; Huberman, A. M. 1994. Qualitative data analysis: an expanded sourcebook. Sage Publications, $338 \mathrm{p}$.

Millward, H.; Byrne, C.; Lewis, A. 2006. Enhancing the design capabilities of small and medium-sized enterprises through knowledge transfer, The Design Journal 9(3): 3-13. https://dx.doi.org/10.2752/146069206789331438

Moultrie, J.; Clarkson, P. J.; Probert, D. 2007. Development of a design audit tool for SMEs, Journal of Product Innovation Management 24: 335-368.

https://dx.doi.org/10.1111/j.1540-5885.2007.00255.x

Nielsen, S. B.; Hoffmann, B.; Quitzau, M. B.; Morten, E. 2009. Mobilizing the courage to implement sustainable design solutions: Danish experiences, $\mathrm{Ar}$ chitectural Engineering \& Design Management 5(1-2): 53-61.

http://dx.doi.org/10.3763/aedm.2009.0906

Novak, V. M. 2014. Design management of sustainability values: a learning organisation perspective, $\mathrm{Ar}$ chitectural Engineering and Design Management 10(3-4): 218-232.

https://dx.doi.org/10.1080/17452007.2014.896782 
OECD / European Communities. 2005. Oslo manual: guidelines for collecting and interpreting innovation data, $3^{\text {rd }}$ ed. Organisation for Economic Cooperation and Development, Paris.

Osterwalder, A.; Pigneur, Y.; Bernarda, G.; Smith, A.; Papadakos, T. 2014. Value proposition design: how to create products and services customers want (strategyzer). Hoboke, NJ: John Wiley \& Sons, $320 \mathrm{p}$.

Persson, H.; Åhman, H.; Yngling, A. A.; Gulliksen, J. 2015. Universal design, inclusive design, accessible design, design for all: different concepts - one goal? On the concept of accessibility - historical, methodological and philosophical aspects, Universal Access in Information Society 14: 505-526. http://dx.doi.org/10.1007/s10209-014-0358-z

Porter, M. E. 1985. Competitive advantage: creating and sustaining superior performance. New York: Free Press, 557 p.

Porter, M. E. 1991. Towards a dynamic theory of strategy, Strategic Management Journal, Special Issue: Fundamental Research Issues in Strategy and Economics 2: 95-117. https://dx.doi.org/10.1002/smj.4250121008

Porter, M. E. 1996. What is strategy?, Harvard Business Review 6: 61-78.

Porter, M. E.; Millar, V. E. 1985. How information gives you competitive advantage, Harvard Business Review 4(63): 149-160.

Prause, G.; Hack, A.; Maknyte (Gerlitz), L. 2012. How to integrate design management concepts into SME? Experiences from the South Baltic Sea Region, in Conference Proceedings of the International Entrepreneurship Forum Entrepreneurship and Sustainability: From Lifestyles to Innovative Enterprises in Creative and Sustainable Environments, 3-6 September 2012, Kuala Lumpur (KL), Malaysia, Vol. 2. Essex, UK, 429-457.

Raulik, G.; Cawood, G.; Larsen, P. 2008. National design strategies and country competitive economic advantage, The Design Journal 11(2): 119-135. https://dx.doi.org/10.2752/175630608X329217

Roy, R.; Reidel, J. C. 1997. Design and innovation in successful product competition, Technovation 17(10): 537-548.

https://dx.doi.org/10.1016/S0166-4972(97)00050-3

Sebastian, R. 2004. Critical appraisal of design management in architecture, Journal of Construction Research 5: 255-266. https://dx.doi.org/10.1142/S1609945104000218
Shaw, E. 1999. A guide to the qualitative research process: evidence from a small firm study, Qualitative Market Research: An International Journal 2: 5970. http://dx.doi.org/10.1108/13522759910269973

Stake, R. E. 1995. The art of case study research, sage publications. California: Thousand Oaks, $175 \mathrm{p}$.

Stamm, B. von. 2004. Innovation - what's design go to do with it?, Design Management Review (15)1: $10-19$.

http://dx.doi.org/10.1111/j.1948-7169.2004.tb00145.x

Svengren, L. 1993. Case study methods in design management research, Design Studies 14(4): 444-456.

http://dx.doi.org/doi:10.1016/0142-694X(93)80017-7

Teece, D. J.; Pisano, G.; Shuen, A. 1997. Dynamic capabilities and strategic management, Strategic Management Journal 18: 509-533.

http://dx.doi.org/10.1002/(SICI)1097-0266(199708)18:7 $<509:: A I D-S M J 882>3.0 . C O ; 2-Z$

Tidd, J.; Bessant, J. 2013. Managing innovation: integrating technological, market and organisational change. $5^{\text {th }}$ ed. John Wiley \& Sons, 680 p.

Trott, P. 2012. Innovation management and new product development, $5^{\text {th }}$ ed. London, $648 \mathrm{p}$.

Turner, R. 2013. Design leadership - securing the strategic value of design. Gower Pub Co. $256 \mathrm{p}$.

Verganti, R. 2008. Design, meanings, and radical innovation: a metamodel and a research agenda, Journal of Product Innovation Management 25: 436456.

http://dx.doi.org/10.1111/j.1540-5885.2008.00313.x

Walsh, V.; Roy, R. 1985. The designer as "gatekeeper" in manufacturing industry, Design Studies 6(3): 127-133. http://dx.doi.org/10.1016/0142-694X(85)90002-X

Walsh, V.; Roy, R.; Bruce, M.; Potter, S. 1992. Winning by design: technology, product design and international competitiveness. Oxford: Blackwell Business: $274 \mathrm{p}$.

Whyte, J.; Bessant, J.; Neely, A. 2015. Management of creativity and design within the firm. DTI Thick Piece, 1-36.

Yin, R. K. 2009. Case study research: design and methods. London: Sage Publications, 219 p.

Yin, R. K. 2012. Applications of case study research, London: Sage Publications, $231 \mathrm{p}$. 